heal the wound in a very simple manner. I would, then, propose :

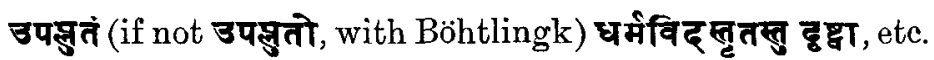

"But the Great Rusii, knowing the Dharma and invincible (as he was), when he perceived the host of Mära overflowing. . . ." Astrta, "invincible," is a Vaidik word, indeed; but this is no reason why Aśvaghoṣa should not have made use of it. There are other instances of such words found in his poems, which in the Petropolitan Dictionary are only exemplified by passages taken from Vaidik texts; for instance, Buddhacarita, II, 54, निपात (observed); II, 36, क्षश्न (gold); VIII, 82, च्रवधृत (fixed); the archaic meaning of "resting" of रेमे, V, 46. Cf. also my note on III, $14 .^{1}$

J. S. SPEYER.

\title{
The Brahmanic and Kshatriya Tradition
}

Mr. Pargiter in the last number of this Journal (pp. 885-904) has discovered in a Pauranic tradition materials for the reconstruction of a most interesting chapter in ancient Indian traditional history, the relation of Visvāmitra and Vasiștha. As his reconstruction ends with a criticism of the distrust of the epic tradition evinced by Professor Macdonell and myself, it is of interest to me to examine the arguments by which the reconstruction and rehabilitation of tradition are carried out.

At the outset of this examination we are confronted by two propositions which are stated by Mr. Pargiter in absolute terms : (1) "The course of all tradition is from the simple and natural to the extravagant and marvellous"; (2) "It is impossible to treat brahmanic tradition as a critical standard, when notoriously the brahmans had

1 [Tibetan chos-kyi-cho-ga seems to imply a reading dharmavidhes.-F. W. T.] 
little or no notion of history". Neither of these propositions is self-evident, and neither, in my opinion, can be regarded as true. In the first place the course of tradition may be from the simple and natural to the extravagant and marvellous, but there is the other side of the question, the fact that since and before Euhemerus man has been prone to employ his intellect to render simple and natural what appears irrational, extravagant, and marvellous. If a version is simpler than another, it may be more primitive; it may equally be an attempt to render simple what was more confused, or merely a brief allusion to what was well known otherwise ; and to apply as of universal validity the test of simplicity as a test of age is to beg the question. The same fallacy, in the second place, affects the attack on the brahmanic notion of history. For whence does Mr. Pargiter derive the evidence for this theory? What conceivable right have we for the period, say to 500 B.c., to make any assertion regarding the brahmanic notions of history in contrast with those of the Kșatriyas? We could only set up a canon if we could contrast the Ksatriya tradition of the Vedic period, say to 500 B.c., with the Brăhmana tradition and see that the former by its coherence and consistency claimed superiority over that of the brahmins. This, however, we cannot do; all that Mr. Pargiter can attempt is (1) to reconstruct a tradition which is to be carried back to the Vedic period, and then (2) to prove that the tradition is superior by contrast with the Brāhmana standard. To assert that the Brähmana tradition is not a critical standard because the brahmins had little or no knowledge of history is a mere petitio principii.

A third objection to Mr. Pargiter's views suggests itself; he distinguishes between a Kṣatriya and a brahmanic tradition, but does not explain the grounds on which this distinction is based. There is a plain and obvious distinction, which has been universally recognized, 
between the sacred Vedic texts, the Samhitās and the Brāhmanas (including the earlier Áranyalkas and Upanisads), and the epic tradition, embodied first and foremost in the two great epics and then in the Purannas. But "the Purānas, as we have them now, are brahmanic compilations", and equally so are the epics, and I am wholly at a loss to see what right we have to select one part as brahmanic, one as Kșatrija tradition.

A further difficulty must be frankly mentioned. "This ballad," we are told, " may well have been handed down by Court bards and then put into writing six or seven centuries B.c." This suggestion is wholly conjectural, and it is well to realize that the story which we are invited to believe existed at the time of the great Brāhmanas is found only in a series of Purānas. The date of these works ( Vāyu, Brahmānda, Brahma, Siva, Linga, and the Harivanssa) cannot by any reasonable possibility be placed before the Christian era-it is unnecessary for my purpose to argue more than that, though their dates may well be a good deal later ${ }^{3}$-and this gives ample room for later manipulation of Vedic tradition.

This, then, is the real problem: we have a Vedic tradition, which is incidentally handed down in a series of sacred texts, dating from before Buddha; it is a tradition of priests, but as priests were the learned men, the bards, at any rate in some cases, of the community, there is no a priori probability that another divergent tradition existed among the Kșatriyas. We do find in texts over 500 years later in date than the Vedic period certain other traditions. We cannot solve questions of priority by the dismissal of brahminical accuracy, but must resort. to an examination of the two legends without prejudice other than the natural preference for the older. The onus probandi lies on those who seek to show that the later contains a purer tradition.
1 p. 889.
2 p. 902 .
3 See JRAS. 1907, p. 681. 
Now the later tradition exists in varied forms, and there are therefore two questions, first to decide the older of the forms, and then to compare that with the Vedic tradition. The traditional version of the dispute between Vasiștha and Viśvāmitra is familiar from the Rămāyana, and it centres in the efforts of Viśvämitra to obtain the status of a brahmin. In the version described by Mr. Pargiter we hear of Satyavrata, son of Trayyāruna, king of Kosala, who for an offence is banished by his father; Vasistha deliberately does not intervene to prevent his banishment, and assumes the government of the realm, the father retiring in vexation to the forest. The banished prince in exile rescued the son, Gālava, of Viśvāmitra, who, engaged in the penance which won him brahminhood, had left his wife and children without adequate means of support. Satyavrata also killed Vasiștha's cow (sarvakāmadugh $\bar{\alpha}$ ), and was thence named by the latter the man of three śankus or sins (Trisanku). On his return from his penance, as a seer, Viśvāmitra restored Satyavrata Triśañku to his kingdom, and raised him in his corporeal body to the sky.

This tale seems to Mr. Pargiter probable and natural as compared with the Rāmāyana version, and this simplicity in his view makes it undoubtedly older than the latter. More specifically he argues that the version could not have been composed when the version in the epics existed, and if composed could not have been admitted into the Purānas. Neither argument has any value; it is a pure assumption that no new version of a legend could be created after the epic legends had come into existence, and, in view of the plain testimony borne by the comparison of epic and Purāna tales in other cases ${ }^{1}$ of the many variant versions of ancient legends current, an

I See e.g. the various versions of the Rsyasinnga episode analysed by Lüders, and those of the Purūravas and other legends examined by Geldner and Sieg. Cf. also JRAS. 1911, p. 1105. 
assumption wholly unjustified. More importance attaches to the argument that the version of a conflict of Viśvamitra and Indra in the Rāma yana is due to a misunderstanding of the name of Vasiștha, Devaräj, which he finds in this narrative. That is the kind of point which is really of importance, if valid. Unhappily in this case it is not valid; it rests on a comparison of two epic verses where devarāt in one corresponds to bhütakrt in the other, and which record that Vasiștha caused all creatures to live in a period of drought; they do not, as Mr. Pargiter says, refer to administration of the kingdom at all, and therefore they in no way illustrate the Purāna legends. Nor in the second place is bhütakrt synonymous with devara $\bar{j}$; the meaning of it, "the creator," is abundantly explained by the verse which ends Prajāpatir iva prajāh: Prajāpati is bhutapati as early as the Brāhmanas, and so the theory that $b h \bar{u}$ takrt $=$ Indra = devara $j$ at once is invalidated. The idea that Devarāj was Vasiștha's personal name and was mistaken for Indra rests accordingly on the weakest foundation. ${ }^{1}$

On the other hand, for the theory that the Purāna version is in no wise primitive, a good deal may be said. It clearly knows the contest regarding Vasiștha's cow (vv. 52-7), and it is guilty of the absurdity in the context in which the episode is placed of treating the ruler of a kingdom as possessing only one cow, as Mr. Pargiter himself points out. But in the Rāmāyana version the cow is that of Vasistha's hermitage and the only cow necessary to a hermit, a clear sign that the epic is more primitive in this regard. Mr. Pargiter himself again admits that the episode of Gālava is suspiciously

1 Mr. Pargiter's further identification of devarāj and divaukas (they are "nearly equivalent", p. 897 , n. 2) leads him into the unhappy conjecture of divaukasam = Vasistha in the place of the picturesque touch by which Satyavrata's interference with the marriage is called an assault on the gods, a touch in full harmony with the religious ceremony of marriage and far from absurd or impossible (p. 894, n. 1). 
like an ætiological explanation of the name; but he does not note that the selling of the boy for a hundred cows and the binding are obviously derived from the Śnahśepa story familiar from the Aitareya Brāhmana. Finally, the episode of Trisanku is equally far from primitive; Mr. Pargiter ${ }^{1}$ himself admits that the etymology is doubtful, but he rationalizes the story by the view that on the death of Trisanku, probably soon after his restoration, in consequence of the hardships he had undergone, Viśvāmitra honoured him by naming a constellation after him. This is Euhemerism with a vengeance, but for our purpose all we need note is that there is absolutely nothing to show that this version is older than the epic; it merely says that Viśnamitra raised the king to heaven with his body, quoting a pair of old stanzas to the effect that Triśanku shines in the sky through Viśvāmitra's favour; this may presuppose the elaborate epic version or it may not. But, taken on the whole, there is no reason to rate as early this piece of bald patchwork, with its wholly unintelligible tale of Vasistha's motive, which Mr. Pargiter ${ }^{2}$ interprets as a priestly seizure of power.

The next question is the relation of this version to the Vedic tradition. Is it the real explanation of the Vedic opposition of Vasiṣtha and Viśvammitra? Here we find that the Vedic tradition has no trace of Satyavrata Trisanku, and that on the contrary the figure of Sudās appears as the king with whom the priests Viśāmitra and Vasiștha stood in connexion; equally the Vedic tradition ignores Gālava-though it contains, as we have seen, the real source of that legend, just as the "wish cow" 3 of Vasistha has an historical connexion with Vedic tradition. How can we reject the Vedic evidence of assured date in favour of this legend, late in its proved

1 p. 903.

2 pp. 895, 900, n. 1 .

3 See Macdonell, Vedic Mythology, p. 150. 
existence, and on all sides full of signs of secondary origin? It is a minor matter that Trayyāruna figures as a Kosala king, and that Tryaruna of the Vedic texts is a prince of what was later the Kuru country.

All the epic versions, however, agree with this account in regarding Viśvāmitra as undergoing penance, and he is in the epics treated as a king who became a brahmin. Mr. Pargiter ${ }^{1}$ defends this view, and holds that the silence of the Rigveda is natural, since he had abandoned his kingly status and resolutely turned his back on the past. But it is equally natural and less imaginative to assume that his kingship is not mentioned in the Rigveda because it did not exist. What is important to note is that the mere fact of the kingship of Viśvámitra, even if admitted, leaves us without any explanation of the importance attached in the epic to his becoming a brahmin. Mr. Pargiter, who recognizes this, finds in the episode of Satyavrata the reason of the struggle, but there is an equally good and much more ancient explanation, the facts connected with the Purohitaship of Sudās.

To sum up, the Vedic tradition shows two priests disputing over the favour and Purohitaship of a prince, Sudās, whose reality is beyond doubt. This tradition cannot reasonably be placed later than 800 B.C., the lowest date for the texts which record it. There are two non-Vedic traditions: one, the epic, deals in great detail with the alleged efforts which Viśvamitra had to make to become a brahmin; the other traces the enmity of Viśvāmitra and Vasiștha to a quarrel in connexion with a prince, Triśanku. Now the first legend in its attitude towards the position of a brahmin as compared with a king is not early Vedic, but it does represent a strain of thought which appears in a simpler form in the Upanișad period of Vedic literature, in which we are

${ }^{1}$ p. 887. 
told, e.g., that Janaka of Videha became a brahmin in the sense at least that he attained the learning of one. The legitimate view is that this story is a later development of sub-Vedic times, and this accords with its late appearance in literature. The other story in its kernel is totally different from the Vedic account of the feud of the two priests; it evidently presupposes that Viśvāmitra was not originally a priest; it operates with a prince, unknown to Vedic fame, whom it identifies with Trisanku, of whom we only know that the old tradition (reported by this version) made him a constellation; it invents a most absurd explanation of his name, and reproduces an old Vedic tale of Śnahiśepa in a mutilated form regarding a certain Gālava. It is in my opinion wholly impossible to see in all this any possible gain to the Vedic tradition; in this case, as in others, it seems to me that the effort to exploit the later texts adds nothing to our knowledge of Vedic times. We can, of course, heap conjecture on conjecture, and erect plausible edifices, but the substructions of our buildings seem to me to be wholly untrustworthy.

Of minor points may be noticed that the argument ${ }^{1}$ that the interpretation of Vidarbha in the version of the Vāyu Purāna as "prince of Vidarbha" must be wrong because the kingdom of Vidarbha did not come into being until later, rests on the assumption that the narrative is one of strict truth and that the date of the founding of the kingdom of Vidarbha can be fixed as later than this epoch, and that neither assumption need be correct. It might plausibly be argued that the severe punishment was due to the enormity of the offence, nor can it be doubted that the Purānas meant "prince of Vidarbha", even if their account is the less primitive. But of this there is no evidence; the explanation of $v v$. 39-40 may be mere special pleading, and the crime have been ${ }^{1}$ p. 893 , n. 10. 
committed after the ceremony was completed. Vidarbha as a citizen's name is surely wholly impossible.

In conclusion, I may add that Mr. Pargiter's criticism ${ }^{1}$ of Professor Macdonell's and my view of Triśanku is again based on a petitio principii. Triśanku, the religious teacher of the Taittiriya Upanisad, is "manifestly different from and later than the king Triśanku". But why? The teacher of the Upanisad was presumably a reality to judge from the way he is referred to, and the king Triśanku is a mythical person who ascends the sky in his own person and moves as a constellation, as the legends which are the sole authority for his personality agree in telling us. To compare these two with Saul the lking and Saul the religious teacher is merely to prejudice the issue. Both of these men were real, but it is a mere assumption that a real Trisanku other than the teacher ever existed.

\section{A. Berriedale KeIth.}

\section{'The Phone'lics of the Wardak Vase}

It is well known that consonants are never written doubled in the Kharosthī script, and the question arises whether, when reading inscriptions in that script, a single consonant may be regarded at times as meaning that consonant doubled. In a note published in this Journal for 1913, p. 141, Sir G. Grierson has put forward the view-“ I would suggest that a consideration of the modern vernaculars of the north-west will show that the assumption that this restoration [i.e. reading a single consonant as doubled] is required is probably wrong, and that the dialect in which these Kharoșthi inscriptions are written pronounced these consonants as single, not as double, letters." He has supported his suggestion with the fact that the languages of the north-west, which he

$$
\text { 'p. } 904 .
$$

